\title{
BIOLOGICAL PECULIARITIES IN THE RESPONSIVENESS OF VEGETABLE CROP ROTATION TO PRECISION FERTILIZATION
}

\author{
A.I. IVANOV1, 2, V.V. LAPA ${ }^{3}$, A.A. KONASHENKOV', Zh.A. IVANOVA1
}

\author{
${ }^{1}$ Agrophysical Research Institute, Federal Agency of Scientific Organizations, 14, Grazhdanskii prosp., St. Peters- \\ burg, 195220 Russia, e-mail office@agrophys.ru, ivanovai2009@yandex.ru (corresponding author); \\ ${ }^{2}$ North-Westt Center for Interdisciplinary Studies Research of Food Supply, Federal Agency of Scientific Organizations, 7, \\ sh. Podbel'skogo, St. Petersburg-Pushkin, 196608 Russia, e-mail szcentr@bk.ru; \\ ${ }^{3}$ Institute for Soil Science and Agrochemistry, 90, vul. Kasinca, Minsk, 220108 Belarus, e-mail brissagro@gmail.com \\ ORCID: \\ Ivanov A.I. orcid.org/0000-0002-1502-0798 \\ Ivanova Zh.A. orcid.org/0000-0002-3138-8285
}

The authors declare no conflict of interests

Received January 27, 2017

\section{Abstract}

Spatial and temporal variability of growing conditions which affects the production process management is characteristic of agrophytocenosis. Spatial heterogeneity of soil essential properties is widely reported. A precision fertilization should be effective tool to control crop productivity. The highest potential of such fertilization could be expected for vegetable crops in the favorable soil and climatic conditions of the Nechernozemie of North-West Russia. In a microvegetation stationary two-factor experiment, plastic bottom-less pots of $1 \mathrm{~m}^{2}$ area were used to artificially form the upper part of the soil profile ( $\mathrm{A}_{\text {arable }} 0-22 \mathrm{~cm}$ and $\mathrm{A}_{2} \mathrm{~B} 22-40 \mathrm{~cm}$ horizons) simulating natural lithogenic mosaics of agro sod-podzolic sandy, sandy loam, light loam and medium loam soils subjected to weak and good cultivation. Their minimum, maximum, and average parameters for the $0-22 \mathrm{~cm}$ horizon were as follows: $\mathrm{pH}_{\mathrm{KCl}}$ of 4.34-6.35 and 5.40, humus content (by Tyurin) of 0.92-2.50 and $1.72 \%$, labile phosphorus and potassium (according to Kirsanov) of $125-550$ and $390 \mathrm{mg} / \mathrm{kg}$ and $22-$ 400 and $209 \mathrm{mg} / \mathrm{kg}$, respectively. The vegetable crop rotation included black radish (Raphanus sativus L.)-potato (Solanum tuberosum L.)-beetroot (Beta vulgaris L.)-cabbage (Brassica oleracea L.)carrot (Daucus sativus L.). For a comparison, we used different system of fertilization, i.e. control (no fertilizers); zonal system (ZS); precision fertilization 1 (PF-1); precision fertilization 2 (PF-2). In the ZS providing for a uniform application of the fertilizers based on the average soil properties, we used lime $\left(4.5 \mathrm{t} / \mathrm{ha}+\mathrm{N}_{95} \mathrm{P}_{20} \mathrm{~K}_{125}\right)$ for black radish; manure $(45 \mathrm{t} / \mathrm{ha})+\mathrm{N}_{100} \mathrm{P}_{30} \mathrm{~K}_{90}$ for potatoes; $\mathrm{N}_{130} \mathrm{P}_{50} \mathrm{~K}_{150}$ for beetroot; lime $(2.1 \mathrm{t} / \mathrm{ha})+$ manure $(50 \mathrm{t} / \mathrm{ha})+\mathrm{N}_{120} \mathrm{P}_{10} \mathrm{~K}_{90}$ for cabbage; and $\mathrm{N}_{100} \mathrm{P}_{40} \mathrm{~K}_{130}$ for carrot. In the PF-1, two months before the radish was sown a precision soil cultivation has been performed using lime at 0-20 and 6.6 t/ha, peat at 0-900 and $390 \mathrm{t} / \mathrm{ha}$; phosphorite flour at $0-750$ and $94 \mathrm{~kg} / \mathrm{ha}$; potassium sulfate at $0-1710$ and $407 \mathrm{~kg} / \mathrm{ha}$ (as $\min -\max$ and average). Further application of organic and mineral fertilizers before sowing (planting) was uniform, i.e. $\mathrm{N}_{70} \mathrm{~K}_{60}$ for black radish; manure $(45 \mathrm{t} / \mathrm{ha})+\mathrm{N}_{80} \mathrm{~K}_{100}$ for potatoes; $\mathrm{N}_{100} \mathrm{P}_{30} \mathrm{~K}_{130}$ for beetroot; manure (50 t/ha) $+\mathrm{N}_{100} \mathrm{P}_{10} \mathrm{~K}_{70}$ for carrot; $\mathrm{N}_{100} \mathrm{P}_{10} \mathrm{~K}_{120}$ for white cabbage. In PF-2 providing average doses of all fertilizers equal to these in $\mathrm{ZS}$, but differentiated for each pot based on actual soil parameters, we used lime $(0-12 \mathrm{t} / \mathrm{ha})+\mathrm{N}_{70-120} \mathrm{P}_{0-90} \mathrm{~K}_{60-200}$ for black radish; manure (30$65 \mathrm{t} / \mathrm{ha})+\mathrm{N}_{80-110} \mathrm{P}_{0-110} \mathrm{~K}_{70-150}$ for potato; $\mathrm{N}_{90-170} \mathrm{P}_{0-150} \mathrm{~K}_{80-240}$ for beetroot; lime $(2.1 \mathrm{t} / \mathrm{ha})+$ manure (30-70 t/ha) $+\mathrm{N}_{110-135} \mathrm{P}_{0-60} \mathrm{~K}_{40-120}$ for cabbage; $\mathrm{N}_{85-115} \mathrm{P}_{10-90} \mathrm{~K}_{79-180}$ for carrot. The experiments were arranged in four replications. In a field experiment the precision fertilization provided an increase in the productivity of vegetable crop rotation of 22.3 and $43.5 \mathrm{t} /$ ha in control and ZS, respectively, to $47.9-49.4 \mathrm{t} / \mathrm{ha}$. PF-1 and PF-2 resulted in the $C v$ reduction from $32 \%$ and $16 \%$ in the control and ZS to $9 \%$, and in an increased natural profitability of fertilizers by 21-49\%. A responsiveness of vegetable crop rotation to precision fertilization depended on biological features, the specific farming techniques and soil conditions. A decreasing responsiveness was as follows: black radish $>$ car-rot $\approx$ beet $>$ potatoes $>$ cabbage. A uniform application of high doses of organic fertilizers was the factor reducing precision fertilization effectiveness. Significant advantage of PF-1 compared to PF-2 was established only for black radish, beet and carrot. When designing precision fertilization technologies, one should take into account the following decrease in sensitivity of vegetable crops in crop rotation to optimized (reduced) doses of fertilizers in the well-cultivated parts of a field: cabbage $>$ beet $>$ carrot $>$ radish black $>$ potatoes. Due to differentiated doses of ameliorants and fertilizers and integrated optimization of soil properties, the precision fertilization eliminates the effect of soil heterogeneity in cultivation and granulometric composition on crop production and 
allows to increase productivity and payback of natural fertilizers to $28-42$ and 21-67 \% in sand, 17 26 and $25-47 \%$ in sandy loam, 30-31 and 49-55 \% in a light loam, and 11-16 and 0-35\% in middle loam soils, when compared to ZS.

Keywords: spatial heterogeneity, the soil, precise fertilization system, culture, vegetable crop rotation, productivity, efficiency

The optimization of production process in olericulture is mostly based on agrotechnologies [1-4]. The time-spatial alteration of growing conditions, which is characteristic of agrophytocenoses, is associated with the weather and climate dynamics [2], phytosanitary state [5, 6], terrain-dependent soil differentiation [711], initial soil heterogeneity [12-15], irregular application of fertilizers and ameliorants [15-17], and is recorded almost everywhere [18-21]. The absence of reliable estimates of soil heterogeneity is still regarded as an important reason of reduced fertilizer efficiency as it was when chemicals were intensively used (in Russia, this was happening in 1970s and 1980s) [1, 2]. The problem required new geoinformation approaches [22-26] and specially planned field experiments $[22,27]$. Together with the experience in controlling plant nutrition, this allowed development of a concept of production process integrated control in agroecosystems [1-3, 28-29] with the view of improving effects of fertilizers, reducing non-productive losses of biogenic elements, and environment protection [30-33].

The instruments here are precise fertilizer regime using non-generalized data of geo-reference study of soil and sowings, information technologies and precision equipment $[2,22,27]$. The non-black soil belt with a contrast and complex soil layer, pronounced heterogeneity of agrophysical and agrochemical properties, soil and climate conditions beneficial for fertilizers is classified among regions perspective for use of precision systems [1-2, 15, 27]. One of the factors defining their performance is the biological features of cultivar and variety nutrition [2, 34-36]. Due to its undervaluation, the advantage of precise fertilizer regime may not manifest itself [33]. Such systems are especially important in olericulture crops different in requirements to soil conditions and nutrition [2, 35-37].

In the present study, we have shown for the first time that precise fertilizing allows carrying out effective vegetable farming despite strongly pronounced deviations in sod-podzolic soil fertility, with the response of different crops to such systems being individual.

The aim of the study was to experimentally assess specifics and parameters of the vegetable crop rotation in response to precise fertilizing on solpodzolic soils with lithogenic mosaic typical for non-black soil belt.

Technique. In the stationary micro-field trials (the experimental station of the Agrophysical Research Institute, Prometheus collective farm, Gdov Province, Pskov Region, 2007-2011) in the polyethylene bottomless vessels of $1 \mathrm{~m}^{2}$, the upper part of the soil profile was formed artificially $\left(0-22 \mathrm{~cm} \mathrm{~A}_{\text {arable }}\right.$ soil horizon and 22-40 $\mathrm{cm} \mathrm{A}_{2} \mathrm{~B}$ soil horizon). For packing vessels, the sod-podzolic sandy, sandy loam, light loam and medium loam soils, of poor and good cultivation, which constitute the contrast soil structure simulating natural lithogenic mosaics [16] were sampled from the corresponding horizons. In the $\mathrm{A}_{\text {arable }}$ horizon, the min-max and average $\mathrm{pH}_{\mathrm{KCl}}$ were 4.34-6.35 and 5.40, respectively, humus content (by Tyurin) was $0.92-2.50$ and $1.72 \%$, mobile phosphorus and potassium (by Kirsanov) amounted 125-550 and $390 \mathrm{mg} / \mathrm{kg}$ and 22-400 and $209 \mathrm{mg} / \mathrm{kg}$, respectively.

The crop rotations studied were black radish (Raphanus sativus L.) Zimnyaya kruglaya chernaya (Federal Research Center for Vegetable Growing, Russia)-potato (Solanum tuberosum L. ) Nevskii (Leningrad Research Institute of Agriculture, Russia)-beetroot (Beta vulgaris L.) Bikores (Bejo Zaden B.V., Netherlands) - cabbage (Brassica oleracea L.) Kuisor $\mathrm{F}_{1}$ (Syngenta Seeds B.V., 
Netherlands)—carrot (Daucus sativus L.) Narbonne $F_{1}$ (Bejo Zaden B.V., Netherlands). The sowing (seeding) patterns were $5 \times 30 \mathrm{~cm}$ (black radish), $20 \times 60 \mathrm{~cm}$ (potato), $5 \times 30 \mathrm{~cm}$ (beetroot), $30 \times 60 \mathrm{~cm}$ (cabbage), and $3 \times 30 \mathrm{~cm}$ (carrot). Good phytosanitary conditions of the sowings were maintained by manual weeding, inter-row treatment, use of fungicides and insecticides.

The two-factor experiments comprised eight factor A variants of the soil including its type (poorly or well-cultured soil) and subtype according to the granulomertic content (sand, sod-podzolic sandy, sandy loam, light loam and medium loam), and also four factor B variants of the type of organomineral fertilizing (control - 0, no fertilizers; zonal fertilization system, ZS; precision fertilization system 1, PF-1; precision fertilization system 2, PF-2). In the ZS, fertilizers were introduced uniformly (based on the average soil properties) as follows: lime $(4.5 \mathrm{t} / \mathrm{ha})+\mathrm{N}_{95} \mathrm{P}_{20} \mathrm{~K}_{125}$ for black radish (30 t/ha root-crop); manure (45 t/ha) $+\mathrm{N}_{100} \mathrm{P}_{30} \mathrm{~K}_{90}$ for potato (40 t/ha bulbs); $\mathrm{N}_{130} \mathrm{P}_{50} \mathrm{~K}_{150}$ for beetroot (30 t/ha root-crops); lime $(2.1 \mathrm{t} / \mathrm{ha})+$ manure $(50 \mathrm{t} / \mathrm{ha})+\mathrm{N}_{120} \mathrm{P}_{10} \mathrm{~K}_{90}$ for cabbage (60 t/ha heads); $\mathrm{N}_{100} \mathrm{P}_{40} \mathrm{~K}_{130}$ for carrot (50 t/ha root-crops). In the PF-1, precise soil cultivation was carried out 2 weeks prior to sowing [16] using longacting ameliorants and fertilizers: lime (on average $6.6 \mathrm{t} / \mathrm{ha}$, min-max 0-20 t/ha), peat (390 t/ha, 0-900 t/ha), phosphorite flour (94 kg/ha of $\mathrm{P}, 0-750 \mathrm{~kg} / \mathrm{ha}$ ), potassium sulfate (407 kg/ha of $\mathrm{K}, 0-1710 \mathrm{~kg} / \mathrm{ha})$. Organic and mineral fertilizers were uniformly introduced prior to sowing (planting) correspondingly to the alteration in soil properties: $\mathrm{N}_{70} \mathrm{~K}_{60}$ for black radish, manure (45 t/ha) $+\mathrm{N}_{80} \mathrm{~K}_{100}$ for potato, $\mathrm{N}_{100} \mathrm{P}_{30} \mathrm{~K}_{130}$ for beetroot, manure $(50 \mathrm{t} / \mathrm{ha})+\mathrm{N}_{100} \mathrm{P}_{10} \mathrm{~K}_{70}$ for cabbage, $\mathrm{N}_{100} \mathrm{P}_{10} \mathrm{~K}_{120}$ for carrot. In the PF-2, average doses of all fertilizers equal to those in the ZS were provided, but differentiated for each pot based on actual soil parameters: lime (0-12 t/ha) $+\mathrm{N}_{70-120} \mathrm{P}_{0-90} \mathrm{~K}_{60-200}$ for radish; manure (30$65 \mathrm{t} / \mathrm{ha})+\mathrm{N}_{80-110} \mathrm{P}_{0-110} \mathrm{~K}_{70-150}$ for potato; $\mathrm{N}_{90-170} \mathrm{P}_{0-150} \mathrm{~K}_{80-240}$ for beetroot; lime $(2.1 \mathrm{t} / \mathrm{ha})+$ manure $(30-70 \mathrm{t} / \mathrm{ha})+\mathrm{N}_{110-135} \mathrm{P}_{0-60} \mathrm{~K}_{40-120}$ for cabbage; and $\mathrm{N}_{85-115} \mathrm{P}_{10-90} \mathrm{~K}_{79-180}$ for carrot. Lime dust, ammonium saltpeter, phosphorite flour, double superphosphate, potassium sulfate, potassium chloride, as to State Standards (Russia), were ameliorants, and peat (humidity $65 \%$, ash $24 \%, \mathrm{pH}_{\mathrm{aq}}$. 6.1 ; $\mathrm{N} 1.05 \%, \mathrm{P}_{2} \mathrm{O}_{5} 0.07 \%, \mathrm{~K}_{2} \mathrm{O} 0.04 \%$ ), pig manure, duff-semi-fusty (humidity 72-75\%, $\mathrm{pH}_{\text {aq. }}$ 6.4-6.8; $\mathrm{N}$ 0.45-0.49 \%, $\mathrm{P}_{2} \mathrm{O}_{5}$ 0.15-0.20\%, $\mathrm{K}_{2} \mathrm{O}$ 0.24-0.29\%) were local fertilizers.

The main and side product output was measured by weighing. The experiment was arranged in 4-fold repetition.

Responsiveness estimates were an average $(M)$, minimum $\left(\mathrm{m}_{\min }\right)$ and maximum $\left(\mathrm{m}_{\max }\right)$ yields, the variation coefficient $(C v, \%)$ and the natural payback of the fertilizer active substance. Results were processed by dispersion analysis (Statistica 7.0, StatSoft, Inc., USA). The reliability of the differences was estimated by $F$ Fischer criterion.

Results. The studies have confirmed the high agronomic effect of differentiation in fertilizer dosages according to spatial soil heterogeneity. Yield variability in the control was 24 to $51 \%$ (Table 1). In the ZS, when calculating optimal ameliorant and fertilizer dosages according to the weight-average agrochemical parameters (a group of the vessels), the crop productivity increased by $95 \%$ compared to control, in the PF-2, with differentiated use of the identical fertilizer the value was $115 \%$ higher compared to the control and $11 \%$ higher than in FS. In the PF-1 with preliminary precision soil cultivation, the parameters were 122 and $14 \%$, respectively. As to fertilizer payback, the precision systems were superior to the zonal one (an increase by $49 \%$ for the PF-1 and by $21 \%$ for the PF-2). The costs of a precision soil culturing modeled for a more prolonged effect were not comprised in the calculation of payback of the PF-1. 
All cultures positively but not identically responded to the fertilizer dosage differentiation. The yield gain in PF-1 and PF-2 increased by 69 and $36 \%$ for radish, by 28 and $26 \%$ for potato, by 39 and $20 \%$ for beetroot, by 21 and $16 \%$ for cabbage, and by 5 and $16 \%$ for carrot with $1.9-2.6-$ and $1.4-1.9-, 1.8-$ 2.4- and 1.3-1.8-; 1.6-1.8- and 1.1-1.3-; 2.2-2.7- and 1.0-1.2-; 2.5-4.3- and 1.42.4-fold decrease in spatial variability $(C v)$ as compared to the control and $\mathrm{ZS}$, respectively, for the same crops.

1. Productivity of vegetable crop rotation and its spatial heterogeneity depending on the fertilizer regimes (field experiment, Pskov Region, 2007-2011)

\begin{tabular}{|c|c|c|c|c|c|c|}
\hline \multirow[b]{2}{*}{ Fertilizer regime } & \multicolumn{3}{|c|}{ Yield, t/ha } & \multicolumn{2}{|c|}{ Yield gain } & \multirow{2}{*}{$\begin{array}{l}\text { Payback of } 1 \mathrm{~kg} \\
\text { NPK (in grain } \\
\text { units) }\end{array}$} \\
\hline & $M$ & $\mathrm{~m}_{\min }-\mathrm{m}_{\max }$ & $C v, \%$ & t/ha & $\%$ & \\
\hline \multicolumn{7}{|c|}{ B lack radish } \\
\hline Control-0 & 14.1 & $7.0-29.0$ & 45 & & & \\
\hline ZS & 21.8 & $15.0-41.0$ & 33 & 7.7 & 55 & 5.1 \\
\hline PF-1 & 27.1 & $23.8-43.0$ & 17 & 13.0 & 92 & 16.0 \\
\hline PF-2 & 24.6 & $18.5-42.0$ & 24 & 10.5 & 74 & 7.0 \\
\hline $\mathrm{LSD}_{05}$ & 1.30 & & & & & \\
\hline \multicolumn{7}{|c|}{ Pot ato } \\
\hline ZS & 53.3 & $28,6-74,2$ & 37 & 31,7 & 147 & 15,7 \\
\hline PF-1 & 62.2 & $38,0-74,0$ & 21 & 40,6 & 188 & 21,9 \\
\hline PF-2 & 61.5 & $30,6-75,4$ & 28 & 39,9 & 185 & 19,8 \\
\hline $\mathrm{LSD}_{05}$ & 2.60 & & & & & \\
\hline \multicolumn{7}{|c|}{ B e e troot } \\
\hline Control-0 & 11.3 & $1,6-22,2$ & 61 & & & \\
\hline ZS & 24.2 & $8,0-35,8$ & 42 & 12,9 & 114 & 4,5 \\
\hline PF-1 & 29.2 & $12,2-41,3$ & 33 & 17,9 & 158 & 7,5 \\
\hline PF-2 & 26.8 & $12,8-40,3$ & 38 & 15,5 & 137 & 5,6 \\
\hline $\mathrm{LSD}_{05}$ & 1.60 & & & & & \\
\hline \multicolumn{7}{|c|}{$\mathrm{Cabb}$ age } \\
\hline Control-0 & 60.5 & $32,0-90,0$ & 24 & & & \\
\hline ZS & 105.1 & $87,0-123,0$ & 11 & 44,6 & 74 & 13,3 \\
\hline PF-1 & 114.3 & $101,0-141,0$ & 9 & 53,8 & 89 & 17,4 \\
\hline PF-2 & 112.4 & $95,0-137,0$ & 11 & 51,9 & 86 & 15,2 \\
\hline $\mathrm{LSD}_{05}$ & 4.40 & & & & & \\
\hline \multicolumn{7}{|c|}{ Carrot } \\
\hline Control-0 & 23.4 & $11,9-35,2$ & 30 & & & \\
\hline ZS & 47.6 & $32,0-60,4$ & 17 & 24,2 & 103 & 9,6 \\
\hline PF-1 & 58.5 & $41,4-69,8$ & 12 & 35,1 & 150 & 15,4 \\
\hline PF-2 & 51.5 & $45,0-58,4$ & 7 & 28,1 & 120 & 11,2 \\
\hline $\mathrm{LSD}_{05}$ & 1.55 & & & & & \\
\hline \multicolumn{7}{|c|}{ Crop rotation (grain units) } \\
\hline Control-0 & 22.3 & $12,8-32,3$ & 32 & & & \\
\hline ZS & 43.5 & $30,7-51,9$ & 16 & 21,2 & 95 & 9,9 \\
\hline PF-1 & 49.4 & $39,6-53,8$ & 9 & 27,1 & 122 & 14,8 \\
\hline PF-2 & 47.9 & $41,1-53,5$ & 9 & 25,6 & 115 & 12,0 \\
\hline $\mathrm{LSD}_{05}$ & 2.07 & & & & & \\
\hline
\end{tabular}

N ot e. $M$ - average value, $C v-$ variation coefficient. In payback calculation, $70 \%$ and $30 \%$ of the NPK manure costs were attributed to the first and the second crop, respectively. For description of the fertilizer regimes see the "Technique" section.

The relative yield gain ranked the crops in an obvious decreasing series according to the response to precision fertilizer regimes, i.e. radish $>$ carrot $\approx$ beetroot $>$ potato $>$ cabbage. A different response was a consequence of differences both in the crop biology and in the fertilizing and agrotechnical methods. In particular, the treatment of potato and cabbage plants with high manure doses in the $\mathrm{ZS}$ led to the partial smoothing of the soil properties and, as a consequence, the PF-1 and PF-2 had less advantage. Thence, these crops, characterized by a high efficiency of nutrient consumption [14, 32-35, were the forth and the fifth in the series in terms of their response to differentiated use of ameliorants and fertilizers and at the maximum payback of fertilizers. As a result, combination of this factor to the biological features of edible root plants, which require soils with higher agrophysical properties, was a reliable advantage of the PF-1 over the PF-2.

The spatial heterogeneity is manifested both in poorly and well-cultured 
soils $[13,16,21]$. Therefore, the differentiation in the fertilizer dosages is justified in the soils of any culturing. However, if the fertilizer regimes are based on the redistribution of ameliorants and fertilizer for the benefit of poorly cultured soils, it is not always possible to maintain yield on the well-cultured level (Table 2). Only radish, potato and carrot (the crops which are more flexible in requirements to soils) $[14,31,33,35]$ did not reduce the productivity at a reduced fertilizer and lime dosages (PF-2). Moreover, potato plants on the well-cultured soil appeared to be more sensitive to lower lime dosage (2.3 instead of $4.5 \mathrm{t} / \mathrm{ha}$ ) when applied for the black radish, with a reliable increase in bulb yield (by $9 \%$ compared to ZS). On the contrary, the productivity of cabbage and beetroot, more sensitive to nutrition condition, reliably decreased (by 6 to $9 \%$ ) with a reduction in fertilizer doses on the well-cultured part of the plot (PF-2). The same was recorded for carrot. Therefore, sensitivity of the studied crops to a reduced fertilizer doses on well-cultured soils decreased as follows: cabbage $>$ beetroot $>$ carrot $>$ radish $>$ potato. On well-cultured soil, PF-1 regime impacts the plants, except cabbage, more steadily and positively leading to 7 to $9 \%$ increase in yield compared to ZS due to the after-effect of preliminary precise culturing.

2. Fertilizer regime efficiency depending on the crop of the crop rotation and soil conditions (field experiment, Pskov Region, 2007-2011)

\begin{tabular}{|c|c|c|c|c|c|c|c|c|c|c|}
\hline \multirow{4}{*}{$\begin{array}{l}\text { Fertilizer regime } \\
\text { (Factor B) }\end{array}$} & \multicolumn{10}{|c|}{ Efficiency under different soil conditions (Factor A) } \\
\hline & \multicolumn{5}{|c|}{ poorly cultured soil } & \multicolumn{5}{|c|}{ well-cultured soil } \\
\hline & \multirow{2}{*}{$\mathrm{Y}, \mathrm{t} / \mathrm{ha}$} & \multirow{2}{*}{$C v, \%$} & \multicolumn{2}{|c|}{ YG } & \multirow{2}{*}{$\mathrm{P}$} & \multirow{2}{*}{$\mathrm{Y}, \mathrm{t} / \mathrm{ha}$} & \multirow{2}{*}{$C v, \%$} & \multicolumn{2}{|c|}{ YG } & \multirow{2}{*}{$\mathrm{P}$} \\
\hline & & & $\mathrm{t} / \mathrm{ha}$ & $\%$ & & & & $\mathrm{t} / \mathrm{ha}$ & $\%$ & \\
\hline \multicolumn{11}{|c|}{ B lack radish } \\
\hline Control-0 & 9.7 & 22 & & & & 19.0 & 32 & & & \\
\hline ZS & 17.7 & 13 & 8.0 & 82 & 5.2 & 26.0 & 32 & 7.0 & 37 & 5.1 \\
\hline PF-1 & 26.3 & 15 & 16.6 & 171 & 20.5 & 27.9 & 26 & 8.9 & 47 & 11.7 \\
\hline PF-2 & 22.3 & 13 & 12.6 & 130 & 7.5 & 26.7 & 35 & 7.7 & 41 & 6.6 \\
\hline \multicolumn{11}{|c|}{$\mathrm{LSD}_{05}$ for $\mathrm{A}$ is 1.90 ; for $\mathrm{B}$ is 1.30 ; for $\mathrm{AB}$ is $3,80 \mathrm{~T} / \mathrm{га}$} \\
\hline & & & & $\mathrm{Po}$ & & & & & & \\
\hline Control-0 & 14.8 & 38 & & & & 28.5 & 29 & & & \\
\hline ZS & 47.6 & 27 & 32.8 & 222 & 16.3 & 59.0 & 15 & 30.5 & 107 & 14.9 \\
\hline PF-1 & 60.1 & 21 & 45.3 & 306 & 24.4 & 64.4 & 11 & 35.9 & 126 & 17.7 \\
\hline PF-2 & 60.0 & 26 & 45.2 & 305 & 19.9 & 63.0 & 12 & 34.5 & 121 & 19.6 \\
\hline \multicolumn{11}{|c|}{$\mathrm{LSD}_{05}$ for $\mathrm{A}$ is 3.70 ; for $\mathrm{B}$ is 2.60 ; for $\mathrm{AB}$ is $7.40 \mathrm{t} / \mathrm{ha}$} \\
\hline & & & & $\mathrm{B} \mathrm{e} \mathrm{e}$ & o ot & & & & & \\
\hline Control-0 & 7.5 & 69 & & & & 15.4 & 43 & & & \\
\hline ZS & 19.8 & 47 & 12.3 & 164 & 4.2 & 30.3 & 29 & 14.9 & 97 & 5.4 \\
\hline PF-1 & 25.7 & 36 & 18.2 & 243 & 7.7 & 32.6 & 28 & 17.2 & 112 & 7.4 \\
\hline PF-2 & 26.0 & 28 & 18.5 & 247 & 5.5 & 28.4 & 30 & 13.0 & 84 & 6.4 \\
\hline \multicolumn{11}{|c|}{$\mathrm{LSD}_{05}$ for $\mathrm{A}$ is 2.30 ; for $\mathrm{B}$ is 1.60 ; for $\mathrm{AB}$ is $4.50 \mathrm{t} / \mathrm{ha}$} \\
\hline & & & & $\mathrm{Ca}$ & $\mathrm{ge}$ & & & & & \\
\hline Control-0 & 49.6 & 15 & & & & 71.4 & 14 & & & \\
\hline ZS & 98.0 & 7 & 48.4 & 98 & 14.5 & 112.4 & 9 & 41.0 & 57 & 12.3 \\
\hline PF-1 & 116.4 & 7 & 66.8 & 135 & 21.6 & 112.1 & 11 & 40.7 & 57 & 13.2 \\
\hline PF-2 & 122.7 & 6 & 73.1 & 147 & 18.1 & 102.1 & 7 & 30.7 & 43 & 11.2 \\
\hline \multirow{2}{*}{\multicolumn{11}{|c|}{$\begin{array}{l}\mathrm{LSD}_{05} \text { for } \mathrm{A} \text { is } 6.20 \text {; for } \mathrm{B} \text { is } 4.40 \text {; for } \mathrm{AB} \text { is } 12.40 \mathrm{t} / \mathrm{ha} \\
\qquad \mathrm{C} \mathrm{a} \mathrm{r} \mathrm{r} \mathrm{ot} \mathrm{(2011} \mathrm{год)}\end{array}$}} \\
\hline & & & & & & & & & & \\
\hline Control-0 & 17.4 & 22 & & & & 29.4 & 12 & & & \\
\hline ZS & 41.5 & 15 & 24.1 & 139 & 9.2 & 53.7 & 8 & 24.3 & 83 & 10.0 \\
\hline PF-1 & 58.4 & 16 & 41.0 & 236 & 16.0 & 58.6 & 6 & 29.2 & 99 & 14.8 \\
\hline PF-2 & 51.8 & 9 & 34.4 & 198 & 11.4 & 51.2 & 5 & 21.8 & 74 & 11.0 \\
\hline \multicolumn{11}{|c|}{$\mathrm{LSD}_{05}$ for $\mathrm{A}$ is 2.19 ; for $\mathrm{B}$ is 1.55 ; for $\mathrm{AB}$ is $4.38 \mathrm{t} / \mathrm{ha}$} \\
\hline \multicolumn{11}{|c|}{ Crop rotation (in grain units) } \\
\hline Control-0 & 16.9 & 20 & & & & 27.8 & 18 & & & \\
\hline ZS & 38.9 & 15 & 22.0 & 130 & 10.2 & 48.2 & 10 & 20.4 & 73 & 9.6 \\
\hline PF-1 & 48.5 & 13 & 31.6 & 187 & 17.6 & 50.4 & 9 & 22.6 & 81 & 13.0 \\
\hline PF-2 & 48.9 & 11 & 32.0 & 189 & 12.6 & 47.0 & 8 & 19.2 & 69 & 11.3 \\
\hline
\end{tabular}

$\mathrm{LSD}_{05}$ for A is 2.94 ; for $\mathrm{B}$ is 2.07 ; for $\mathrm{AB}$ is $5.86 \mathrm{t} / \mathrm{ha}$

$\mathrm{N}$ o t e. $C v-$ variation coefficient; $\mathrm{Y}-$ yield, $\mathrm{YG}-$ yield gain, $\mathrm{P}-$ payback of $1 \mathrm{~kg}$ NPK (in grain units). For description of the fertilizer regimes see the "Technique" section.

The advantage of PF-1 and PF-2 was expectably especially significant in poorly cultured soil with an increase in yield gain by 49 and $26 \%$ for radish, 26 and $26 \%$ for potato, 30 and $31 \%$ for beetroot, 19 and $25 \%$ for cabbage, 41 
and $25 \%$ for as compared to ZS. Despite the expectations, only for radish and carrot in the poorly cultured soil, the precise technology providing for complex optimization of agrophysical and agrochemical properties of all soil subtypes was more preferable than the PF-2. For potato, cabbage and beetroot under relatively beneficial weather and climate conditions, the optimization of soil properties due to the redistribution of ameliorants, organic and mineral fertilizers just prior to planting (sowing) (PF-2) appeared to be sufficient. As a result, in the crop rotation the reliable advantage of the PF-1 over the PF-2, with $18 \%$ increase in productivity, was recorded only in well-cultured soils. In these regimes, the payback of fertilizers increased more significantly (from 15 to $40 \%$ ).

In our experiment, agrophysical heterogeneity of soils was predominantly associated with granulomertic composition. For potato, beetroot and carrot productivity the $C v$ values, which reflect the sensitivity to soil heterogeneity, in the control was 1.3 to 1.8 times higher in poorly cultured soil than in the wellcultured one, that for cabbage almost did not change, and that for radish decreased 1.5-fold. The pronounced distinction of the latter from the other crops is possibly associated with the peculiarities of its development in the second half of vegetation period after the soil remained semi-fallow for a long time. In this time, due to prolonged (up to mid-July) incubation, in the well-cultured sands, sandy loams, light and medium loam soils a pronounced heterogeneity in nitrogen regimen is formed due to microorganisms, which determines a high variability of yield in radish having a shortened period of active root nutrition. The precise fertilizing allowed for almost completely avoiding differences in productivity of the corps in poorly and well-cultured soils, reducing the $C v 1.5$ to 1.8 -fold and 2.0 to 2.3 -fold, respectively.

Although the fertilizers provided a high absolute and relative yield gain for all soils, the effect of granulomertic composition was quite remarkable (Fig.). The complex effect of this factor on yield formation had a more fundamental character. Quite in compliance with biological features and requirements of the crops [14, 33-35], at high soil heterogeneity without fertilizing the yield of radish (19.6 t/ha) and cabbage (69.5 t/ha) was higher in the medium loam soil, the yield of potato $(28.4 \mathrm{t} / \mathrm{ha})$, beetroot $(18.7 \mathrm{t} / \mathrm{ha})$ and carrot $(27.6 \mathrm{t} / \mathrm{ha})$ was higher in light loam soil, and the minimum parameters were recorded for sand. Thus, the yields reflected the crop preferences to air and water conditions and nutrition depending on soil types as follows: medium loam $>$ light loam $>$ sandy loam $>$ sand for radish and cabbage; light loam $>$ medium loam $>$ sandy loam $>$ sand for potato; light loam $>$ sandy loam $>$ medium loam $>$ sand for beetroot and carrot. As a whole, the productivity of crop rotation on sand substrate was minimal $(17.1 \mathrm{t} / \mathrm{ha}$ g.u.) at a minimum absolute gain for ZS of $19.0 \mathrm{t} /$ ha g.u. against $23.7 \mathrm{t} / \mathrm{ha}$ g.u. on other soils. The precise fertilizing have neutralized the effect of this factor, and the yield gain per rotation for PF-1 and PF-2 reached 26.2-27.5 and 24.426.4 t/ha g.u., respectively. Thereby, the PF-1 and PF-2 efficiency as compared to ZS was 42 and $28 \%$ higher on sand, 26 and $17 \%$ higher on sandy loam, 31 and $30 \%$ higher on light loam, and 16 and $11 \%$ higher on medium loam soil.

The variability in the yield and, correspondingly, in the crop rotation productivity also depends on soil granulomertic parameters. Thus, for radish and potato the maximum values of $C v$ were recorded in light and medium loam (42 to 45 and 34 to $71 \%$ ), for beetroot - in sandy loam and sand (54 to $75 \%$ ), for cabbage and carrot - in medium loam and sand (24 to 25 and 32 to $38 \%$ ) soils. Despite the commonly adopted conception of increased requirements of cabbage to agrophysical and agrochemical soil properties, its sensitivity to the granulomertic composition remained minimal. This was facilitated by normal watering 
of the crop under the acutely arid vegetation period in 2010. For the crop rotation as a whole, the maximum $C v$ values were recorded for sandy and light loam soils in the control (25 to $34 \%$ ) with minimum for PF-1 and PF-2 (1 to $10 \%$ ) and intermediate values for ZS (8 to $15 \%$ ) (irrespectively of a granulomertic composition).

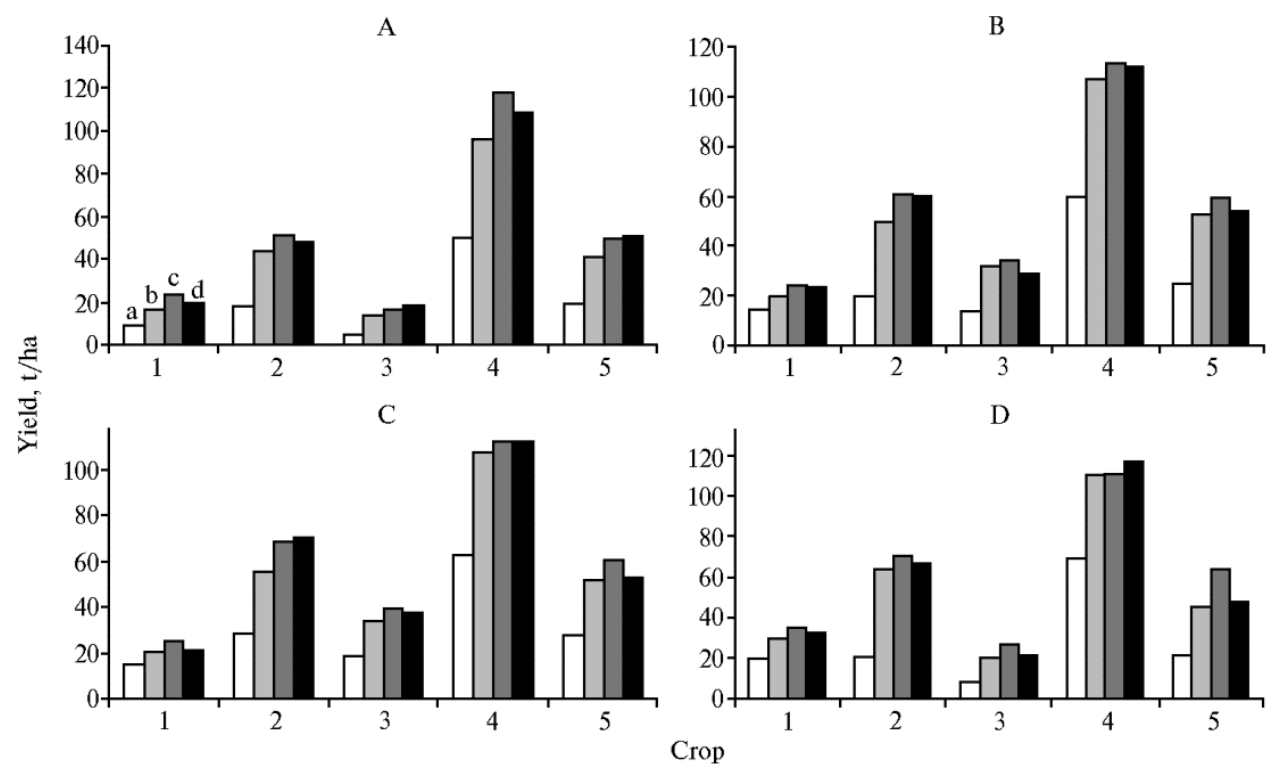

Crop yields in the vegetable crop rotation depending on soil types and fertilizing regime: A - sand, B - sandy loam, C - light loam, D - medium loam; 1, 2, 3, 4, 5 - black radish, potato, beetroot, cabbage, carrot, respectively; a, b, c, d - control-0, ZS, PF-1, PF-2 (for the description of fertilizing regimes see the "Technique" section) (field experiment, 2007-2011).

Thus, under high heterogeneity and lithogenic mosaic of sod-weakly podzolic soils, the precise and annually differentiated use of organic and mineral fertilizing (the PF-2 regime) or single precise use of ameliorant and subsequent uniform introduction of fertilizers (the $\mathrm{PF}-1$ regime) provided an increase in the vegetable crop rotation productivity (in grain units) from 22.3 to $43.5 \mathrm{t} / \mathrm{ha}$ in control and in using zonal fertilization system (ZS) up to 47.9 to 49.4 t/ha (by 115-122 and 10-14\%, correspondingly). Thereby, the $C v$ values for the crop rotation productivity reduced from 32 and $16 \%$ in the control and ZS to $9 \%$, and the natural payback of the fertilizers increased by 21 to $49 \%$. The crop response to the precise fertilizing decreased in the crop rotation as follows: radish $>$ carrot $\approx$ beetroot $>$ potato $>$ cabbage. A reliable advantage of the PF- 1 regime over the PF-2 has been established only in edible roots (radish, beetroot and carrot). The reduction in the payback of the precise fertilizing compared to zonal one was due to uniformly introduced high doses of organic fertilizers. When developing fertilizing systems for vegetable crop rotations, one should take into the account that the crop sensitivity to optimization (reduction) of fertilizer dosages in well-cultured parts of the field reduces as follows: cabbage $>$ beetroot $>$ carrot $>$ radish $>$ potato. The precise fertilizing, owing to differentiated dosages of ameliorants and fertilizers and complex optimization of soil properties, have eliminated the effect of soil different culturing and granulomertic composition. As a result, the increase in the productivity and natural payback of fertilizers compared to those in ZS was 28 to 42 and 21 to $67 \%$ in sand, 17 to 26 and 25 to $47 \%$ in sandy loam, 30 to 31 and 49 to $55 \%$ in light loam, and 11 to 16 and 0 to $35 \%$ in medium loam soil. 


\section{REFERENCES}

1. D e r z h a vi n L.M. Agrokhimiya, 2013, 8: 18-29 (in Russ.).

2. Ivanov A.I., Konashenkov A.A., Ivanova Zh.A., Vorob'ev V.A., Fesen k o M.A., Danilova T.A., Fili p p ov P.A. Agrofizika, 2016, 2: 35-44 (in Russ.).

3. Robert P.C. Precision agriculture: a challenge for crop nutrition management. Plant Soil, 2002, 247(1): 143-149 (doi: 10.1023/A:1021171514148).

4. L a p a V., L o m o n o s M. Crop yield and quality depending on fertilization in crop rotation on sod-podzolic soil. In: Soil as World Heritage. D. Dent (ed.). Springer Netherlands, 2014: 303-308 (doi: 10.1007/978-94-007-6187-2_29).

5. S h p a n e v A.M. Agrofizika, 2016, 2: 24-34 (in Russ.).

6. Ta ngw o ngkit R., S a lokhe V.M., J a y s u ri y a H.P.W. Development of a real-time, variable rate herbicide applicator using machine vision for between-row weeding of sugarcane fields. Agriculture, 2006, 8: 1-12.

7. Lu P., S u Y.-R., Ni u Z., W u J.-S. Nongye yu shengming kexue. Zhejiang daxue xuebao, 2007, 33(1): 89-95.

8. S o o n Y.K., M a 1 hi S.S. Soil nitrogen dynamics as affected by landscape position and nitrogen fertilizer. Can. J. Soil Sci., 2005, 85(5): 579-587 (doi: 10.4141/S04-072).

9. Sh pedt A.A., P u r la u r V.K. Sibirskii vestnik sel'skokhozyaistvennoi nauki, 2008, 10: 5-11 (in Russ.).

10. Zhang S., Zhang X., Huffman T., Liu X., Yang J. Influence of topography and land management on soil nutrients variability in Northeast China. Nutr. Cycl. Agroecosyst., 2011, 89(3): 427-438 (doi: 10.1007/s10705-010-9406-0).

11. Samsonova V.P., M e shalkina Yu.L. Vestnik Moskovskogo universiteta, Seriya 17: Pochvovedenie, 2014, 3: 36-44 (in Russ.).

12. Akbas F., Gunal H., Gokmen F., Gezging S., Ersahin S. Spatial variation of micronutrients in topsoil and subsoil of Fertic Haplustepts. Agrochimica, 2009, 53(2): 101-116.

13. B a s e v i c h V.F., Te t e n' k i n V.L. Vestnik Moskovskogo universiteta, Seriya 17: Pochvovedenie, 2010, 2: 35-42 (in Russ.).

14. Knyazhneva E.V., Nadezhkin S.M., Frid A.S. The spatial heterogeneity of the fertility in a leached chernozem within a field. Eurasian Soil Sc., 2006, 39(9): 1011-1020 (doi: 10.1134/S1064229306090110).

15. Ivanov A.I., Konashenkov A.A., Khomyakov Yu.V., Fomenko T.G., F e d ' k i n I.A. Agrokhimiya, 2014, 2: 39-49 (in Russ.).

16. Iv a nov A.I., Ko n a s e n k o v A.A. Agrokhimiya, 2012, 6: 66-72 (in Russ.).

17. Fomenko T.G., Pavlova V.P., Iv a nov A.I. Problemy agrokhimii $i$ ekologii, 2012, 4: 8-13 (in Russ.).

18. Scherpinski C., Uribe-Opaso M.A., Vilas B.M.A., Sampaio S.C. Variabilidade espacial da condutividade hidraulica e da infiltracao da agua no solo. Acta Scientiarum. Agronomy, 2010, 32(1): 7-13 (doi: 10.4025/actasciagron.v32i1.959).

19. Zhang X.-Y., Sui Y.-Y., Zhang X.-D., Meng K., He rbert S.J. Spatial variability of nutrient properties in black soil of Northeast China. Pedosphere, 2007, 17(1): 19-29 (doi: 10.1016/S1002-0160(07)60003-4).

20. G a 11 a rd o A. Spatial variability of soil properties in a floodplain in Northwest Spain. Ecosystems, 2003, 6: 564-576 (doi: 10.1007/s10021-0030198-9).

21. G a 11 a rd o A., P a r a m a R. Spatial variability of soil elements in two plant communities of NW Spain. Geoderma, 2007, 139: 199-208 (doi: 10.1016/j.geoderma.2007.01.022).

22. Yakushev V.P., Le k o m ts ev P.V., Pet rushin A.F. Informatsiya $i$ kosmos, 2014, 3: 50-56.

23. Badenko V., Kurtener D., Yakushev V.P., Torbert A., B ad e nko G. Evaluation of current state of agricultural land using problem-oriented fuzzy indicators in GIS environment. Lect. Notes Comput. Sc., 2016, 9788: 57-69 (doi: 10.1007/978-3-319-42111-7_6).

24. Ko roleva I.E., Frid A.S. Tentative separation of soil-agrochemical areas on a plowland and their relation with the relief and plant productivity. Eurasian Soil Sc., 2006, 39(12): 13441351 (doi: 10.1134/S1064229306120106).

25. Zinkevicius R. Influence of soil sampling for precision fertilizing. Agron. Res., 2008, 6(Spec. Issue): 423-429.

26. S c h n e id e r M., Wag ne r P., H e rbst R., Ertragspotential sichern. Intelligente probungGrundlage fur differenzierte Grunddungung. Neue Landwirtschaft, 2008, 8: 48-51.

27. Ivanov A.I., Konashe n kov A.A. Sel'skokhozyaistvennye mashiny i tekhnologii, 2014, 3: 20-24 (in Russ.).

28. Frossard E., Buneman E., Jansa J., Oberson A., Foller C. Concepts and practices of nutrient management in agro-ecosystems: Can we draw lessons from history to design future sustainable agricultural production systems? Bodenkultur, 2009, 60(1): 43-60. 
29. Pla c ht e r H., Sta chow U., We r n e r A. Methoden zur naturschutzfachlichen Konkretisirung der "Guten fachlichen Praxis» in der Landwirtschaft. Bonn-Bad Godesberg, 2005.

30. L a p a V.V. Problemy upravleniya, 2007, 4: 43-48 (in Russ.).

31. Ange rmai r W., Lo re nz F. Dungung nach Diagnose. Neue Landwirtschaft, 2009, 3: 70-73.

32. Herbst R., Rettberg T. Mehr Prazision moglich. Teilflachenspezifische Grundungung bisher zu wenig beachtet. Neue Landwirtschaft, 2005, 2: 44-47.

33. Ka ng T.-H., S ugi u ra R., Nog u chi N. Growth analysis and variable rate fertilizer application of wheat field using multi-spectrum image sensor. Environ. Contr. Biol., 2006, 44(3): 207-214.

34. G re n a d e rov S.V., B o ris o v V.A. Kartofel' $i$ ovoshchi, 2010, 4: 10 (in Russ.).

35. B o r i s o v V.A. Kartofel' $i$ ovoshchi, 2009, 8: 12-13 (in Russ.).

36. Litvinov S.S., B or i s ov V.A., R o m a nova A.V., P o ly a k ov A.A. Vladimirskii zemledelets, 2012, 1: 20-21 (in Russ.).

37. Litvinov S.S., Chutcheva Yu.V., Shatilov M.V., B a shkirov A.V. Ekonomika sel'skogo khozyaistva Rossii, 2016, 6: 37-43 (in Russ.). 